\title{
Ishak Score Unknown
}

National Cancer Institute

\section{Source}

National Cancer Institute. Ishak Score Unknown. NCI Thesaurus. Code C159868.

Unknown Ishak score. 